\title{
KESESUAIAN LAHAN UNTUK KEDELAI EDAMAME DI DESA PURWOBINANGUN KECAMATAN PAKEM KABUPATEN SLEMAN
}

\section{(LAND SUITABILITY FOR EDAMAME SOYBEAN IN PURWOBINANGUN VILLAGE PAKEM SUB-DISTRICT SLEMAN REGENCY)}

\author{
Muhammad Ali Ma'sum ${ }^{\text {I) }}$, (artoyo $^{\left.2)^{*}\right)}$, M. Kundarto ${ }^{2)}$ \\ 1) Prodi Agroteknologi, Fakultas Pertanian, UPN "Veteran" Yogyakarta \\ 2) Prodi Ilmu Tanah, Fakultas Pertanian, UPN "Veteran" Yogyakarta \\ ${ }^{*}$ Corresponding author E - mail: partoyo@ upnyk.ac.id
}

\begin{abstract}
Edamame soybean has various health benefits and high economic value. The large demand for edamame soybeans makes the government provide alternative for farmers to cultivate. Edamame soybean can produce optimally if in accordance with the growing conditions. The aim of this study is to evaluate land suitability for the edamame soybean in Purwobinangun Village, Pakem Sub- District, Sleman Regency. Method used in this research was survey method to know the general condition of the area and purposive method to determine sampling points based on Land Unit Map obtained from overlying of slope map, altitude map and land use map. Land suitability was analyzed according to the FAO framework. The result shows that the actual land suitability class for edamame soybean is $\mathrm{S} 3$ (marginaly suitable) with limiting factors for each different location are drainage, soil texture, $\mathrm{K}_{2} \mathrm{O}, \mathrm{K}_{2} \mathrm{O}$, C-organic, and slope. Efforts to improve land suitability class are by improving drainage, applying organic matter, fertilizing and making terraces.
\end{abstract}

Keywords: land suitability, vegetable soybean, FAO framework, Sleman

\begin{abstract}
ABSTRAK
Tanaman kedelai edamame merupakan tanaman yang memiliki berbagai khasiat untuk kesehatan dan memiliki nilai ekonomis yang tinggi. Banyaknya permintaan akan kedelai edamame menjadikan pemerintah memberikan alternatif tanaman pangan bagi para petani untuk membudidayakan. Tanaman kedelai edamame dapat menghasilkan produksi yang optimal jika sesuai dengan syarat tumbuhya. Oleh sebab itu penelitian ini penting untuk mengetahui bagaimana kriteria kelas kesesuaian lahannya. Penelitian ini bertujuan untuk mengevaluasi kesesuaian lahan untuk budidaya tanaman kedelai edamame di Desa Purwobinangun, Kecamatan Pakem, Kabupaten Sleman. Penelitian ini menggunakan metode survey untuk mengetahui kondisi umum wilayah dan metode purposive untuk penentuan titik sampel berdasarkan SPL (Satuan Peta Lahan) yang diperoleh dari hasil overlay peta kemiringan lereng, peta ketinggian tempat dan peta tata guna lahan. Analisis kesesuaian lahan dilakukan menurut kerangka FAO. Hasil penelitian menunjukkan bahwa kelas kesesuaian lahan aktual untuk tanaman kedelai edamame adalah S3 (sesuai marjinal) dengan faktor pembatas yaitu drainase, tekstur tanah, $\mathrm{N}$-total, $\mathrm{P}_{2} \mathrm{O}_{5}, \mathrm{pH}, \mathrm{C}$-organik, dan kemiringan lereng. Upaya untuk meningkatkan kelas kesesuaian lahan adalah dengan memperbaiki drainase, pemberian bahan organik, pemupukan dan pembuatan terasering.
\end{abstract}

Kata Kunci : kesesuaian lahan, kedelai edamame, kerangka FAO, Sleman 


\section{PENDAHULUAN}

Desa Purwobinangun Kecamatan Pakem yang termasuk ke dalam kawasan Taman Nasional Gunung Merapi, memiliki potensi air yang cukup melimpah, dan memiliki suasana sejuk dan asri. Warga Desa Purwobinangun sebagian terbesar bekerja sebagai petani dan kegiatan pertanian memberikan sumbangan terbesar pada pendapatan desa. Pemda DIY merencanakan untuk menjadikan semua desa di Kecamatan Pakem sebagai pemasok sayur untuk seluruh wilayah Yogyakarta dan sekitarnya. Oleh karena itu, upaya pemanfaatan lahan untuk produksi pertanian harus diperhatikan sebaik-baiknya agar memberikan produksi secara optimal. Peningkatan produksi pertanian dapat dilakukan dengan memperhatikan kesesuaian lahan dengan tanaman yang akan dibudidayakan. Tanah di Desa Purwobinangun termasuk jenis regosol. Regosol merupakan jenis tanah yang baru terbentuk, ditandai dengan masih banyaknya bahan kasar ukuran kerikil yang belum melapuk secara sempurna. Tanah ini terbentuk dari hasil erupsi Gunung Merapi sehingga tergolong jenis regosol abu vulkanik. Tanah regosol abu vulkanik sangat kaya unsur hara, kecuali unsur nitrogen. Namun demikian, hara tanah tersebut belum siap digunakan oleh tanaman karena belum dalam keadaan tersedia.

Kedelai edamame (Glycine max (L.) Merill) atau yang sering disebut edamame adalah jenis kedelai yang memiliki nilai jual yang lebih tinggi dibandingkan dengan kedelai biasa. Ukuran biji edamame lebih besar dibandingkan dengan kedelai biasa. Bobot 100 polong kedelai edamame kira-kira 30 g dengan jumlah biji per polong 2-4 biji. Tinggi tanaman berkisar antara $30 \mathrm{~cm}$ sampai lebih dari $50 \mathrm{~cm}$ dengan bercabang sedikit atau banyak (Widati dan Iteu, 2012). Polong dan biji bertekstur lembut, dengan aroma kacang yang kuat dan warna bulu abu-abu. Daya hasil polong muda mencapai 3,5 ton/ha, lebih tinggi dibandingkan dengan daya hasil kedelai biasa yang rata-rata hanya bekisar 1,7 - 3,2 ton/ha. Tanaman edamame sebagian besar tumbuh di daerah subtropis. Tanaman ini menghendaki suhu udara optimal berkisar $20^{\circ}-25^{\circ} \mathrm{C}$ dan penyinaran matahari penuh. Tanaman edamame dapat tumbuh baik di daerah dengan curah hujan antara 100-400 mm/bulan. Sedangkan untuk mendapatkan hasil yang optimal, tanaman edamame membutuhkan curah hujan antara 100-200 mm/bulan (Pambudi, 2013). Edamame dapat tumbuh baik pada tanah-tanah aluvial, regosol, grumosol, latosol, dan andosol. Toleransi kemasaman tanah sebagai syarat tumbuh optimal bagi edamame adalah $\mathrm{pH}$ 5,5 - 7,5. Pada $\mathrm{pH}$ kurang dari 5,5 pertumbuhannya sangat terlambat karena keracunan aluminium (Worwood, 2014).

Permintaan pasar global terhadap kedelai edamame terbilang cukup tinggi. Indonesia hanya dapat memenuhi kebutuhan pasar Jepang sebesar 3\%, sedangkan 97\% sisanya dipenuhi oleh China dan Taiwan. Menurut data Kementerian Pertanian Republik Indonesia pada tahun 2018 berhasil mengekspor 9 ribu ton edamame di pasarpasar mancanegara seperti Jepang, Amerika Serikat, Australia, Malaysia, serta beberapa negara di Eropa dan Timur Tengah. Permintaan kedelai edamame yang semakin meningkat menjadikan peluang membudidayakan kedelai edamame menjadi sangat terbuka. Namun demikian, pengembangan penanaman kedelai edamame dalam skala luas masih membutuhkan informasi mengenai potensi lahan, kesesuaian lahan, serta tindakan pengelolaan yang tepat untuk meningkatkan produktifitas. Kesesuaian lahan adalah tingkat kecocokan sebidang lahan untuk suatu penggunaan tertentu baik untuk bidang pertanian maupun non pertanian. Penilaian evaluasi kesesuaian lahan dapat dilakukan berdasarkan kondisi biofisik untuk macam penggunaan lahan yang 
direncanakan dan menghasilkan tingkat kesesuaian sangat sesuai, cukup sesuai, sesuai marginal, dan tidak sesuai untuk penggunaan spesifik. Hasil evaluasi lahan akan memberikan informasi dan arahan penggunaan lahan yang diperlukan untuk mewujudkan harapan produksi yang diinginkan. Penelitian ini dilakukan untuk mengevaluasi kesesuaian lahan untuk kedelai edamame, khususnya untuk wilayah Desa Purwobinangun.

\section{BAHAN DAN METODE}

Penelitian dilaksanakan di Desa Purwobinangun, Kecamatan Pakem, Kabupaten Sleman, Daerah Istimewa Yogyakarta. Analisis sampel tanah dilakukan di Laboratorium Balai Penelitian Lingkungan Pertanian (BALINGTAN), Pati. Alat yang digunakan dalam penelitian ini meliputi peralatan lapangan dan studio yang meliputi antara lain GPS, klinometer, altimeter, bor tanah, meteran saku, kantong plastik, kamera, laptop dan software Arc GIS 10.2, serta peralatan laboratorium untuk penetapan $\mathrm{C}$ - organik, N-total, P-tersedia, $\mathrm{K}_{2} \mathrm{O}$, KTK tanah, dan $\mathrm{pH}$. Bahan yang digunakan terdiri atas sampel tanah dari setiap lokasi sampling, peta penggunaan lahan skala $1: 42.000$, peta kemiringan lereng skala $1: 42.000$, peta ketinggian tempat skala 1 : 42.000, data curah hujan, data temperatur udara, data kelembaban udara, dan bahan kimia untuk analisis sampel tanah di laboratorium. Penelitian dilaksanakan dengan metode survei dengan melakukan peninjauan serta pengamatan langsung di lapangan. Penentuan lokasi untuk melakukan pengamatan dan pengambilan sampel tanah dilakukan menggunakan metode purposive sampling berdasarkan peta satuan lahan yang dibuat dengan cara overlay peta tataguna lahan, peta kemiringan lereng, dan peta ketinggian tempat. Adapun peta lokasi pengamatan dan pengambilan sampel berdasarkan peta satuan lahan disajikan pada Gambar 1.

Desa Purwobinangun memiliki wilayah dengan luas sekitar 1.294 ha. Hasil overlay menunjukkan 8 satuan lahan yang terbentuk dan ditetapkan 11 lokasi pengamatan dan pengambilan sampel tanah. Sampel tanah yang diambil merupakan sampel tanah yang mewakili tanah satuan lahan pada lokasi pengambilan sampel. Evaluasi kesesuaian lahan dalam penelitian ini dilakukan dengan membandingkan (matching) antara karakteristik lahan dari hasil pengamatan lapangan dan hasil analisis sampel tanah di laboratorium dengan kriteria kesesuaian lahan untuk tanaman kedelai edamame seperti terlihat di Tabel 1 (Djaenuddin et al., 2011; Pambudi 2013). Klas kesesuaian lahan mengikuti kerangka evaluasi lahan FAO (FAO, 1976).

\section{HASIL DAN PEMBAHASAN}

\section{Data Iklim}

Data curah hujan selama 10 tahun (2009-2018) yang dicatat di Stasiun Bronggang, Cangkringan diperoleh dari BMKG Mlati Yogyakarta. Data temperatur dan kelembaban udara yang dicatat di Pos Pengamatan Gunung Merapi, Kaliurang diperoleh dari BPPTKG Yogyakarta. Adapun data iklim yang diperoleh adalah sebagai berikut:

A. Curah hujan rata-rata tahunan sebesar 2.956,5 mm/tahun. Berdasarkan kriteria kesesuaian lahan aktual untuk kedelai edamame, data curah hujan ini menunjukkan klas S2 (cukup sesuai). 
B. Temperatur udara rata-rata tahunan, dengan rincian sesuai ketinggian tempat, yaitu ketinggian $200-600 \mathrm{mdpl}: 2{ }^{\circ} \mathrm{C}$, ketinggian $601-1000 \mathrm{mdpl}: 21,7^{\circ} \mathrm{C}$, dan ketinggian $>1000 \mathrm{mdpl}: 20^{\circ} \mathrm{C}$.

C. Data ini menunjukkan bahwa temperatur udara di lokasi penelitian menunjukkan klas S1 atau sangat sesuai. Kedelai edamame menghendaki suhu optimum $20^{\circ}-$ $25^{\circ} \mathrm{C}$.

D. Kelembaban rata-rata tahunan: $82,75 \%$. Kelas kesesuaian lahan aktual kedelai edamame berdasarkan data kelembaban udara adalah S2 (cukup sesuai).

E. Tipe iklim (Schmidt and Ferguson): C (agak basah, Q: 38,55\%). Tipe iklim ini termasuk sesuai untuk tanaman kedelai edamame yang memerlukan cukup air untuk pertumbuhan tanaman.
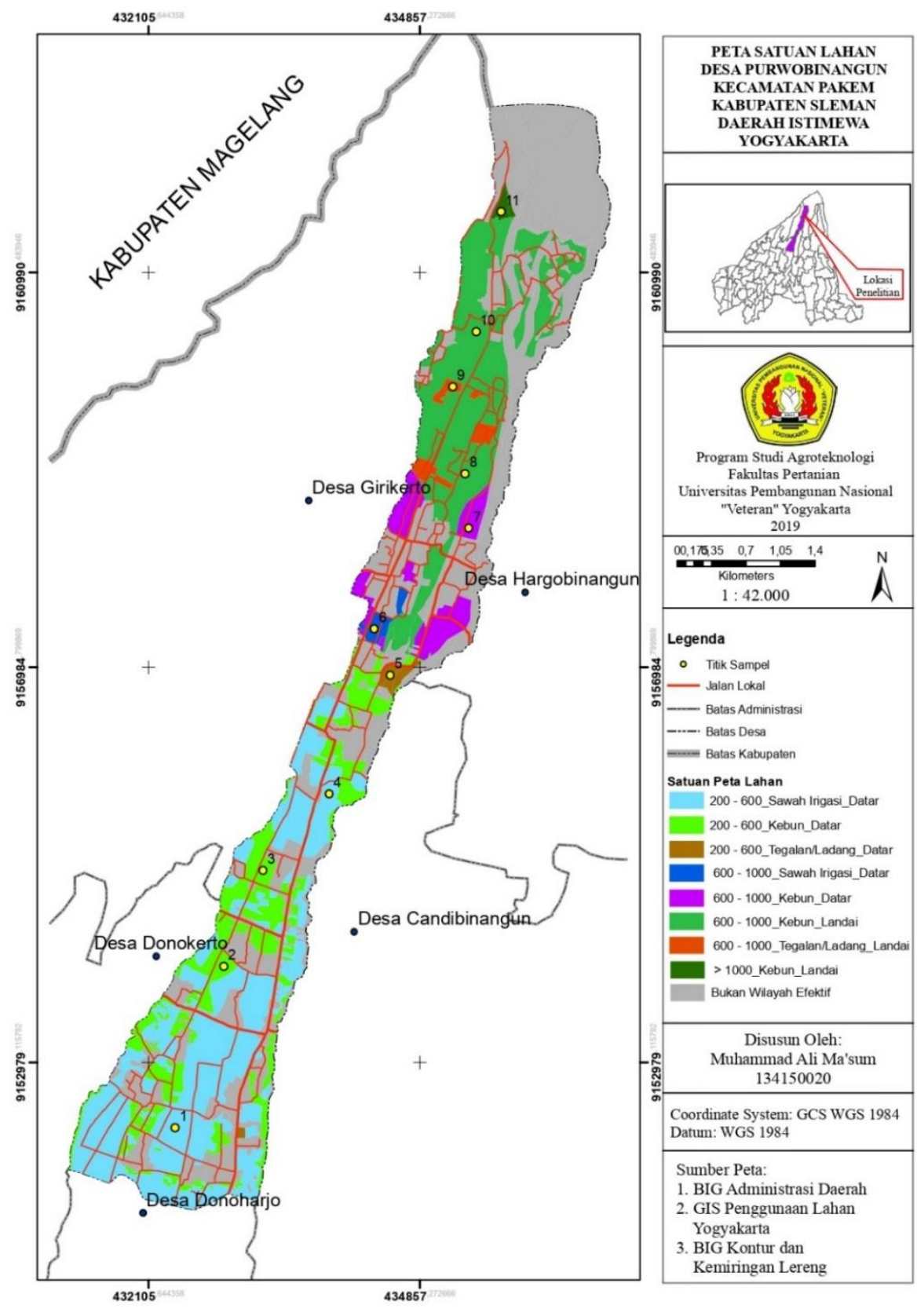

Gambar 1. Peta Satuan Lahan 
Tabel 1. Kriteria Kesesuaian Lahan untuk Tanaman Edamame (Djaenuddin, 2011), dimodifikasi oleh Pambudi (2013)

\begin{tabular}{|c|c|c|c|c|c|}
\hline \multirow{2}{*}{ No } & \multirow{2}{*}{$\begin{array}{c}\text { Persyaratan penggunaan/ Kelas } \\
\text { Kesesuaian lahan karakteristik } \\
\text { lahan } \\
\end{array}$} & \multicolumn{4}{|c|}{ Kelas Kesesuaian Lahan } \\
\hline & & S1 & $\mathbf{S 2}$ & $\mathbf{S 3}$ & $\mathbf{N}$ \\
\hline 1 & Temperatur (tc) & & & & \\
\hline & - Temperatur rerata $\left({ }^{\circ} \mathrm{C}\right)$ & $20-25$ & $\begin{array}{l}16-20 \\
25-28\end{array}$ & $\begin{array}{l}12-15 \\
29-30\end{array}$ & $\begin{array}{l}<12 \\
>30\end{array}$ \\
\hline 2 & Ketersediaan Air (wa) & & & & \\
\hline & - Curah hujan (mm/bulan) & $100-200$ & $\begin{array}{c}200-300 \\
50-100\end{array}$ & $\begin{array}{l}300-400 \\
\quad<50\end{array}$ & $>400$ \\
\hline & - Kelembaban & $24-80$ & $\begin{array}{l}20-24 \\
80-85\end{array}$ & $\begin{array}{l}<20 \\
>85\end{array}$ & \\
\hline 3 & Ketersediaan Oksigen (oa) & & & & \\
\hline & - Drainase & Baik, sedang & $\begin{array}{l}\text { Agak cepat, } \\
\text { agak } \\
\text { terhambat }\end{array}$ & Terhambat & $\begin{array}{l}\text { Sangat } \\
\text { terhambat, cepat }\end{array}$ \\
\hline 4 & Media Perakaran (rc) & & & & \\
\hline & Tekstur & $\begin{array}{l}\text { Halus, agak } \\
\text { halus, sedang }\end{array}$ & $\begin{array}{l}\text { Halus, agak } \\
\text { halus, sedang }\end{array}$ & Agak kasar & Kasar \\
\hline & - Bahan kasar (\%) & $<15$ & $15-30$ & $35-55$ & $>55$ \\
\hline & - Kedalaman tanah $(\mathrm{cm})$ & $>75$ & $50-75$ & $20-50$ & $<20$ \\
\hline 5 & Gambut & & & & \\
\hline & - Ketebalan $(\mathrm{cm})$ & & & $<60$ & $>60$ \\
\hline & - Kematangan & & & Saprik, hemik & Fibrik \\
\hline 6 & Retensi hara (nr) & & & & \\
\hline & - $\quad$ KTK $\operatorname{tanah}(\mathrm{cmol} / \mathrm{kg})$ & $>16$ & $5-16$ & $<5$ & \\
\hline & - Kejenuhan basa (\%) & $>35$ & $20-35$ & $<20$ & \\
\hline & - $\mathrm{pH} \mathrm{H}_{2} \mathrm{O}$ & $5,5-7,5$ & $\begin{array}{c}5,5-5,57,5- \\
7,8\end{array}$ & $\begin{array}{l}<5,0 \\
>7,8\end{array}$ & \\
\hline & - $\mathrm{C}-\operatorname{organik}(\%)$ & $>1,2$ & $0,8-1,2$ & $<0,8$ & \\
\hline 7 & Hara tersedia (nr) & & & & \\
\hline & - $\quad \mathrm{N}-$ Total $(\%)$ & Sedang & Rendah & Sangat rendah & \\
\hline & - $\mathrm{K}_{2} \mathrm{O}(\mathrm{mg} / 100 \mathrm{~g})$ & Tinggi & Sendang & $\begin{array}{l}\text { Rendah - } \\
\text { sangat rendah }\end{array}$ & \\
\hline & - $\mathrm{K}_{2} \mathrm{O}(\mathrm{mg} / 100 \mathrm{~g})$ & Tinggi & Sendang & $\begin{array}{c}\text { Rendah - } \\
\text { sangat rendah }\end{array}$ & \\
\hline 8 & $\begin{array}{l}\text { Toksisitas (xe) } \\
-\quad \text { Salinitas }(\mathrm{dS} / \mathrm{m})\end{array}$ & $<4$ & $4-6$ & $6-8$ & $>8$ \\
\hline 9 & $\begin{array}{l}\text { Sodisitas (xn) } \\
\text { - } \quad \text { Alkalinitas/ESP (\%) }\end{array}$ & $<15$ & $15-20$ & $20-25$ & $>25$ \\
\hline 10 & $\begin{array}{l}\text { Bahaya sulfidik (xs) } \\
\text { - Kedalaman sulfidik }(\mathrm{cm})\end{array}$ & $>100$ & $75-100$ & $40-75$ & $<40$ \\
\hline 11 & $\begin{array}{l}\text { Bahaya erosi }(\mathbf{e h}) \\
\text { - } \quad \text { Lereng }(\%) \\
\text { - } \quad \text { Bahaya Erosi }\end{array}$ & $<3$ & $\begin{array}{c}3-8 \\
\text { Sangat ringan }\end{array}$ & $\begin{array}{l}8-15 \\
\text { Ringan }- \\
\text { Sedang }\end{array}$ & $\begin{array}{c}>15 \\
\text { Berat }- \\
\text { Sangat berat }\end{array}$ \\
\hline 12 & $\begin{array}{l}\text { Bahaya banjir/ genangan pada m } \\
\text { - } \quad \text { Tinggi }(\mathrm{cm}) \\
\text { - } \quad \text { Lama (hari) }\end{array}$ & sa tanam (fh) & - & $\begin{array}{l}25 \\
<7\end{array}$ & $\begin{array}{l}>25 \\
\leq 7\end{array}$ \\
\hline 13 & $\begin{array}{l}\text { Penyiapan Lahan (lp) } \\
\text { - } \quad \text { Batuan di permukaan (\%) } \\
\text { - } \quad \text { Singkapan }(\%) \\
\end{array}$ & $\begin{array}{l}<5 \\
<5\end{array}$ & $\begin{array}{l}5-15 \\
5-15\end{array}$ & $\begin{array}{l}15-40 \\
15-25\end{array}$ & $\begin{array}{l}>40 \\
>25\end{array}$ \\
\hline
\end{tabular}




\section{Karakteristik Lahan}

A. Ketersediaan oksigen (oa)

Drainase tanah di lokasi penelitian termasuk sangat baik karena dipengaruhi oleh jenis tanah regosol yang memiliki permeabilitas yang tinggi sehingga mudah meloloskan air. Beberapa lokasi pengamatan menunjukkan drainase yang buruk, terbukti adanya lapisan tanah dengan bercak-bercak kelabu, coklat dan kekuningan yang menandakan fase reduktif. Kelas kesesuaian lahan aktual untuk kedelai edamame adalah S3 (sesuai marjinal) sampai S1 (sangat sesuai).

B. Media perakaran (rc)

1) Tekstur tanah di lokasi penelitian termasuk S3 (sesuai marjinal) karena memiliki tekstur geluh pasiran. Tanah dengan tekstur yang didominasi pasir mempunyai porositas yang baik namun punya kesuburan yang rendah dimana unsur hara mudah tercuci atau terlindi.

2) Bahan kasar di lokasi penelitian untuk satuan lahan 1, 4, 5 dan 7 termasuk kelas S1 (sangat sesuai). Sedangkan satuan lahan 2, 3, 6 dan 8 termasuk kelas S2 (cukup sesuai) untuk tanaman kedelai edamame.

3) Kedalaman efektif tanah di lokasi penelitian untuk satuan lahan 1 dan 4 termasuk kelas S2 (cukup sesuai) dan untuk satuan lahan yang lain termasuk kelas $\mathrm{S} 1$ (sangat sesuai) yaitu berkisar $>75 \mathrm{~cm}$.

Secara umum, variabel media perakaran (rc) menunjukkan faktor pembatas berupa tekstur tanah. Permasalahan untuk tekstur tanah tidak dapat dilakukan usaha perbaikan yang dapat meningkatkan kelas kesesuaian lahan.

C. Retensi hara (nr)

1) Kapasitas Pertukaran Kation (KTK) tanah di lokasi penelitian berkisar antara 11,09 - 19,02 me\%, dan tergolong dalam kategori rendah sampai sedang. Menurut Hakim et al. (1986) besar KTK tanah dipengaruhi oleh sifat dan ciri tanah antara lain $\mathrm{pH}$, tekstur tanah, jenis mineral, bahan organik, pengapuran dan pemupukan. Kelas kesesuaian lahan aktual untuk kedelai edamame adalah S2 (cukup sesuai) sampai S1 (sangat sesuai).

2) Kejenuhan basa tanah di lokasi penelitian berkisar antara 26,34 - 43,19\% tergolong rendah sampai sedang. Hal ini dimungkinkan karena tingginya curah hujan sehingga kandungan basa-basa yang dapat dipertukarkan semakin rendah karena proses pencucian berjalan intensif. Pada lahan yang terbuka, proses pencucian ini dapat terjadi lebih intensif lagi. Di Desa Purwobinangun kejenuhan basa tidak berhubungan erat dengan $\mathrm{pH}$ tanah, karena tekstur tanah yang dirajai oleh pasir sangat kasar. Menurut Notohadiprawiro (1985) hubungan antara $\mathrm{pH}$ dan kejenuhan tidak berlaku pada tanah yang kaya bahan organik, dirajai oleh lempung bermuatan aneka, kation tertukarkan dirajain oleh $\mathrm{Na}$ atau bertekstur sangat kasar (kadar pasir sangat tinggi). Kelas kesesuaian lahan aktual untuk kedelai edamame adalah S2 (cukup sesuai) sampai S1 (sangat sesuai).

3) $\mathrm{pH} \mathrm{H}_{2} \mathrm{O}$ tanah di lokasi penelitian berkisar antara 7,2 - 7,9. Kelas kesesuaian lahan aktual kedelai edamame termasuk S2 (cukup sesuai) sampai S1 (sangat sesuai). Usaha perbaikan yang dapat dilakukan adalah menambahkan pupuk anorganik yang bersifat masam seperti urea.

4) C-organik tanah di lokasi penelitian berkisar $0,52-1,98 \%$ tergolong sangat 
rendah sampai rendah. Hal ini disebabkan karena lahan sering terkena material vulkanik sehingga kehilangan banyak organisme yang menyebabkan rendahnya pasokan bahan organik alami dan kecepatan mendekomposisi sisasisa organisme menjadi berkurang. Kelas kesesuaian lahan aktual untuk kedelai edamame termasuk S3 (sesuai marjinal) sampai S1 (sangat sesuai).

Kodisi retensi hara (nr) memiliki faktor pembatas berupa C-organik yang rendah. Usaha perbaikan yang dapat dilakukan adalah menambahkan bahan organik dan maupun anorganik seperti lempung untuk meningkatkan funsi koloid dalam tanah.

D. Hara tersedia (na)

1) N-total tanah di lokasi penelitian berkisar antara antara $0,16-0,31 \%$ termasuk dalam kelas S1 (sangat sesuai) dan S2 (cukup sesuai). Dalam tanah, kadar N sangat bervariasi tergantung pada pengelolaan dan penggunaan tanah tersebut (Rosmarkam \& Yuwono, 2002).

2) $\mathrm{K}_{2} \mathrm{O}$ tanah di lokasi penelitian berkisar antara 0,29 - 5,96 termasuk dalam kelas S3 (sesuai marjinal). Hal ini disebabkan karena unsur P yang berada dalam tanah mengalami pelindihan karena air hujan. Rendahnya kandungan $\mathrm{P}$ dalam tanah juga bisa disebabkan karena $\mathrm{pH}$ tanah. Pada $\mathrm{pH}$ tinggi unsur $\mathrm{P}$ terikat oleh $\mathrm{Ca}$ dan $\mathrm{Mg}$ sehingga menjadi tidak tersedia oleh tanaman.

3) $\mathrm{K}_{2} \mathrm{O}$ tanah di lokasi penelitan berkisar antara $6,36-39,50 \mathrm{mg} / 100 \mathrm{~g}$ termasuk dalam kelas S3 (sesuai marjinal) sampai S2 (cukup sesuai). Hal ini disebabkan oleh $\mathrm{K}$ berada keadaan belum tersedia bagi tanaman, belum mengalami perombakan oleh mikroorganisme sehingga masih perlu penambahan bahan organik untuk mempercepat perombakan unsur $\mathrm{K}$ sendiri.

Kondisi hara tersedia (na) memiliki faktor pembatas berupa ketersediaan $\mathrm{K}_{2} \mathrm{O}$ dan $\mathrm{K}_{2} \mathrm{O}$. Usaha yang perlu dilakukan untuk meningkat kelas kesesuaian lahan adalah pemberian pupuk anorganik seperti TSP dan SP36 sebagai sumber P serta pupuk $\mathrm{KCl}$ sebagai sumber $\mathrm{K}$.

E. Bahaya erosi (eh)

1) Kemiringan lereng di lokasi penelitian berkisar antara $1-9 \%$ tergolong $\mathrm{S} 3$ (sesuai marjinal) sampai S1 (sangat sesuai). Kemiringan lereng menjadi faktor penghambat karena dapat terjadi erosi apabila dilakukan pengolahan lahan secara intensif.

2) Bahaya erosi di lokasi penelitian termasuk tingkat yang sangat rendah termasuk dalam kelas S1 (sangat sesuai). Hal ini disebabkan tanah regosol dapat menyerap air dengan cepat sehingga tidak terjadi limpasan permukaan (run off) serta banyaknya vegetasi yang menutupi lahan. Di lokasi penelitian tidak ditemukan adanya gejala erosi.

F. Penyiapan lahan (lp)

1) Batuan permukaan pada satuan lahan 6 memiliki batuan di permukaan $5 \%$ termasuk dalam kelas S2 (cukup sesuai), sedangkan untuk satuan lahan yang lain termasuk dalam kelas S1 (sangat sesuai).

2) Singkapan batuan pada satuan lahan 3 adalah $2 \%$ tergolong kelas sedikit sedangkan untuk satuan lahan yang lain tidak terdapat singkapan batuan. 
Berdasarkan data singkapan batuan, lahan di Desa Purwobinangun termasuk dalam kelas S1 (sangat sesuai) sehingga tidak mengganggu pertumbuhan tanaman kedelai edamame.

Oleh karena adanya beberapa faktor pembatas kesesuaian lahan yang termasuk ke dalam kelas S3, maka secara umum klas kesesuaian lahan untuk tanaman edamame di Desa Purwobinangun, Pakem, Sleman, DIY termasuk ke dalam klas S3 (sesuai marjinal) (Tabel 2). Beberapa faktor pembatas tersebut ada yang dapat diperbaiki sehingga bisa menjadi lebih sesuai untuk mendukung budidaya edamame. Sebaran lahan menurut klas kesesuaiannya terlihat dalam Gambar 2.

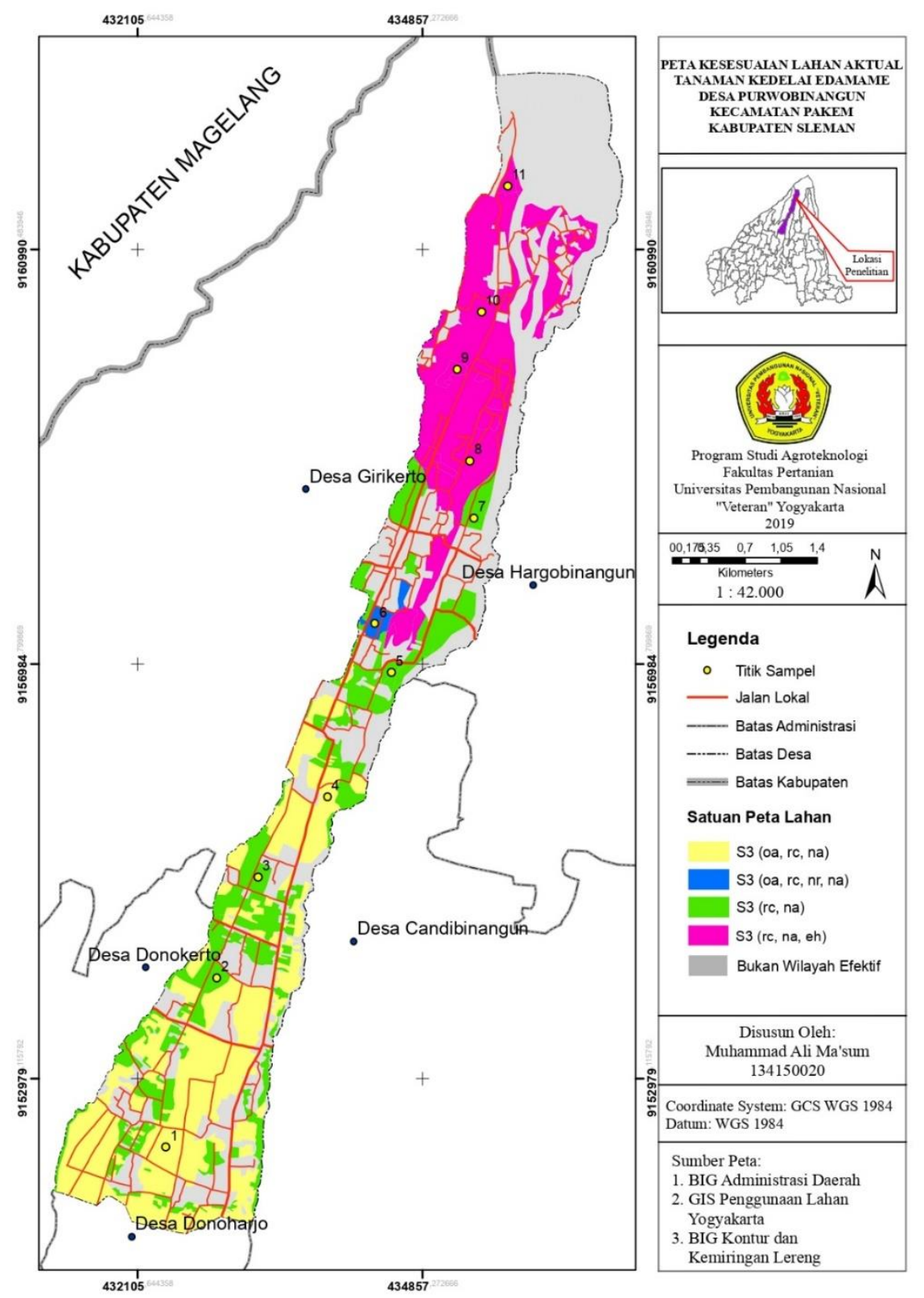

Gambar 2. Peta Kesesuaian Lahan Aktual untuk Kedelai Edamame di Desa Purwobinangun, Kecamatan Pakem, DIY 
Tabel 2. Kelas Kesesuaian Lahan Aktual untuk Kedelai Edamame di Desa Purwobinangun, Kecamatan Pakem, DIY

\begin{tabular}{lcc}
\hline \multicolumn{1}{c}{ Kelas Kesesuaian Lahan } & Luasan Lahan (ha) & Persentase (\%) \\
\hline S3 (oa, rc, na) & 305,63 & 23,82 \\
S3 (oa, rc, nr, na) & 8,18 & 0,64 \\
S3 (rc, na) & 209,43 & 16,31 \\
S3 (rc, na, eh) & 241,13 & 18,79 \\
Luar wilayah efektif penelitian & 518,89 & 40,44 \\
\hline \multicolumn{2}{c}{ Jumlah } & 1283,26 \\
\hline
\end{tabular}

\section{KESIMPULAN}

1. Kelas kesesuaian lahan aktual di Desa Purwobinangun termasuk kelas S3(oa, rc, na) dengan luas wilayah 305,63 ha dengan persentase $23.82 \%$ dari total wilayah, kelas $\mathrm{S} 3$ (oa, rc, nr, na) memiliki luas wilayah 8,18 ha dengan persentase $0,64 \%$, kelas S3(rc, na) memiliki luas wilayah 209,43 ha dengan persentase $16,31 \%$, kelas S3(rc, na, eh) memiliki luas wilayah 241,13 ha dengan persentase $18,79 \%$.

2. Beberapa faktor pembatas untuk tanaman kedelai edamame di Desa Purwobinangun adalah tekstur tanah kasar, drainase cepat, $\mathrm{C}$-organik sangat rendah, $\mathrm{P}_{2} \mathrm{O}_{5}$ sangat rendah, $\mathrm{K}_{2} \mathrm{O}$ sangat rendah dan kemiringan lereng.

3. Peta kesesuaian lahan untuk tanaman kedelai edamame setelah diperbaiki faktor pembatasnya menjadi S3 (rc) dengan faktor pembatas tekstur tanah.

\section{DAFTAR PUSTAKA}

Djaenuddin, D., H. Marwan, H. Subagyo, dan Hidayat, A. 2011. Petunjuk Teknis Evaluasi Lahan untk komoditas Pertanian. Bogor: Balai Penelitian Tanah, Puslibangtanak. Badan Penelitian dan Pengembangan Pertanian

FAO, 1976. A Framework for Land Evaluation. Soil Resources Management and Conservation Service. Land and Water Development Division. FAO Soil Bulletin No. 32. FAO-UN. Rome.

Hakim, N., Yusuf, M., Nugroho, S.G., G.B. Hong, dan Bailey, H. 1986. Dasar-dasar Ilmu Tanah. Lampung: Universitas Lampung.

Notohadiprawiro, T. 1985. Selidik Cepat Ciri Tanah di Lapangan. Jakarta: Ghalia Indonesia Pambudi, S. 2013. Budidaya \& Khasiat Kedelai Edamame Camilan Sehat dan Multi Manfaat. Yogyakarta: Pustaka Baru Press.

Rosmarkam, A dan N.W. Yuwono. 2002. Ilmu Kesuburan Tanah. Yogyakarta: Kanisius Widati, F dan M.H. Iteu. 2012. Kedelai Sayur (Glycine max L. Merrill) sebagai Tanaman Pekarangan. Iptek Holtikultura.08 : 25-28.

Worwood, D. 2014. Edamame in the Garden. Horticulture Vegetables 2014-04pr. USU Extension Educator. 